ISSN 0258-7122

Bangladesh J. Agril. Res. 35(1) : 179-187, March 2010

\title{
EFFECTIVENESS OF THREE INSECTICIDES AGAINST MUSTARD APHID AND PREDATOR UNDER FIELD CONDITION
}

\author{
A. K. M. M. MAULA ${ }^{1}$, M. M. R. SHAH ${ }^{2}$, N. A. SIDDQUIE ${ }^{3}$ \\ M. A. A. MAMUN ${ }^{3}$ AND M. BEGUM ${ }^{4}$
}

\begin{abstract}
Studies were conducted in the field to determine the effectiveness of three insectidicdes, Metasystox-R 25EC, Dimethion 40 EC, and Fentro 50 EC applied against mustard aphid, Lipaphis erysimi Kalt. and measure their toxic action on the predator Coccinella septempunctata L. The mustard plants were sprayed with the insecticides at $0.05 \%$ and $0.025 \%$ a. i. at 50 and 70 days after sowing. The mortality of both mustard aphid and the predator was assessed at 1, 4, and 7 days after first and second spraying of insecticides. Metasystox-R showed the most effectiveness among the three insecticides causing the highest mortality of mustard aphid followed by Dimethion and Fentro. But the lowest mortality of Coccinella septempunctata was obtained in Dimethion treated plot, and Fentro treated plot showed the highest mortality indicating that the Dimethion was less toxic and Fentro was more toxic to the predator.
\end{abstract}

Keywords : Effectiveness, insecticides, mustard aphid, predator.

\section{Introduction}

Mustard (Brassica sp.) is one of the major oil seed crop in Bangladesh and its performance in total oil seed production is approximately 70 percent. It covers an area of 0.34 million ha of land where 0.25 million tons of rape seed and mustard (Anon., 2001a) are produced. This quantity is not sufficient. Bangladesh imports 0.10 million tons of oil to meet her annual requirement, which costs Tk. 261.39 million (Anon., 2001b). The average yield of mustard per ha is very low in Bangladesh. One of the factors responsible for such low yield is the ravage of insect pest attacking at various stages of the crop. Among them, Lipaphis erysimi Kaltenbach, (Aphididae: Homoptera), commonly known as mustard aphid, is the most devastating pest (Rouf and Kabir, 1997) in Bangladesh and is distributed in many other countries (Setokuchi, 1983). The yield loss due to aphid infestation in mustard ranged from 87.16 to $98.16 \%$ (Anon., 1995).

The mustard aphid occurs in the field from December to February. Both the adults and nymphs of this aphid cause damage to mustard plants from seedling to maturity, but maximum damage is caused at flowering stage (Ahmed and Jalil,

\footnotetext{
${ }^{1}$ Upazilla Agriculture Officer, Paba, Rajshahi, ${ }^{2}$ Scientific Officer, Entomology Division, Agricultural Research Station, BARI, Shyampur, Rajshahi, ${ }^{3 \& 4}$ Scientific Officer, OnFarm Research Division, Region-1, BARI, Shyampur, Rajshahi, ${ }^{5}$ Senior Scientific Officer, Entomology Division, BINA, Mymensingh, Bangladesh.
} 
1993). The aphids suck sap from leaves, flowers, flower-buds, pod and twigs of the plants. They also secrete sticky honeydew which acts as a medium for sooty mold fungus development and reduce the photosynthetic efficiency of the plants. In case of severe infestation, leaves become curled, plant fails to develop pods, the young pods when developed fail to become mature and cannot produce healthy seeds. As a result, plants loose their vigour and growth becomes stunted (Morzia and Huq, 1991). The predacious coccinellid beetles, commonly known as lady bird beetles are considered to be of great economic importance in the agro-ecosystem. They have been successfully employed in the bio-control to many injurious insects (Agarwala et al., 1988). In the field mustard aphid population is naturally controlled to a large extent by its predator Coccinella septempunctata and plays a vital role in lowering the population of mustard aphid in the field (Kalra, 1988). For controlling the mustard aphid successfully and to save $C$. septempunctata, insecticides should be applied at appropriate dose and at right time. The present study was conducted to find out the relative effectiveness of three insecticides, Metasystox-R 25EC, Dimethion 40 EC, and Fentro 50 EC against mustard aphid and their toxic effect on the predator Coccinella septempunctata.

\section{Materials and Method}

This study was conducted at the research farm of Bangladesh Institute of Nuclear Agriculture (BINA), Mymensingh. Three insecticides, namely Metasystox-R 25EC, Dimethion 40 EC, and Fentro 50 EC were sprayed against mustard aphid, $L$. erysimi. Two different concentrations of each insecticide at $0.05 \%$ and $0.025 \%$ a.i. were used. Control plots were not treated with any insecticides. First spray of insecticides was done at 50 and second was at 70 days after sowing (DAS). BINA Sarisha-4, Brassica napus L. of mustard variety was considered as test crop. Mustard seeds were collected from the Genetics and Plant Breeding Division, BINA, Mymensingh. The experiment was conducted in randomized complete block design (RCBD) with 3 replications. The unit plot size was $5 \mathrm{~m} \times 4 \mathrm{~m}$. The spacing between block to block, plot to plot were $\mathrm{Im}$ and $0.5 \mathrm{~m}$, respectively. The total area was $660 \mathrm{~m}^{2}$. The plots were exposed to natural infestation. The selected three insecticides were sprayed in the field by a Knapsack sprayer at the dose of $0.05 \%$ and $0.025 \%$ when the inflorescence, leaves and shoots were found infested by aphids. Insecticides were sprayed at 4 p.m.

\section{Percentage of aphid infested plant}

Number of aphid infested mustard plants were recorded at 1, 4, and 7 days after first and second spraying of insecticides. Total number of infested and uninfested plants were counted from five randomly selected rows of each plot and calculated the percent infestation of mustard plants. 


\section{Number of aphids per plant}

The population of aphids in the field on the five randomly selected plants from each plot were counted at 1,4 , and 7 days after first and second spraying of insecticides. The top $10 \mathrm{~cm}$ apical twigs of these selected plants were cut and brought to the laboratory in polythene bags separately. The aphids were removed from the plants with the help of a soft brush and placed on a piece of white paper. Their number was counted with the help of a magnifying glass and tally counter. The number of aphids per plant were converted into percent reduction of aphid population over the control.

\section{Number of $C$. septempunctata per plant}

Ten selected plants from each plot were selected randomly for counting the population of the predator at 1,4 , and 7 days after first and second spraying of insecticides. Then the number of predators per plant were converted into percent reduction of predator over the control. Results obtained for different parameters were statistically analyzed using one factor Randomized Complete Block Design (RCBD) and DMRT.

\section{Results and Discussion}

\section{Effect of insecticides on reduction of aphid infested mustard plants after first spray}

The results on percent reduction of aphid infested plants of different treatments after 1, 4, and 7 days of first spraying are presented in Table 1. At 1 DAT (Days After Treatment) the highest percent reduction of aphid infested plant (71.36\%) was observed in the Metasystox-R treated plot at high dose $(0.05 \%)$, which was followed by its low dose $(0.025 \%)$. The lowest percent reduction of aphid infested plants (46.20\%) was observed in the Fentro treated plots at low dose and was followed by its high dose. At 4 DAT, the highest percent reduction of aphid infested plants (80.40\%) was observed in the Metasystox-R treated plot with high dose which was followed by its low dose, and high dose of Dimethion. The lowest percent reduction of aphid infested plants (60.50\%) was observed in the Fentro treated plants applied at low dose. At 7 DAT, the highest percent reduction of aphid infested plants was found (67.67\%) in the Metasystox-R sprayed plot with high dose and it was statistically identical with that of its low dose, and high dose of Dimethion. The lowest percent reduction of aphid infested plants (40.00\%) was observed in Fentro treated plots applied at low dose. 
Table 1. Percentage of reduction of aphid infested mustard plant after first spray of insecticides.

\begin{tabular}{|c|c|c|c|c|c|}
\hline \multicolumn{2}{|c|}{ Name of insecticides } & \multirow{2}{*}{$\begin{array}{c}\text { Dose } \\
(\%)\end{array}$} & \multicolumn{3}{|c|}{ Reduction of aphid infested plants (\%) } \\
\hline Trade name & Common name & & $1 \mathrm{DAT}$ & $4 \mathrm{DAT}$ & $7 \mathrm{DAT}$ \\
\hline \multirow[t]{2}{*}{ Metasystox-R 25EC } & \multirow{2}{*}{$\begin{array}{l}\text { Oxydemeton } \\
\text { methyl }\end{array}$} & 0.05 & $71.36 \mathrm{a}$ & $80.40 \mathrm{a}$ & $67.67 \mathrm{a}$ \\
\hline & & 0.025 & $68.00 \mathrm{ab}$ & $74.40 \mathrm{ab}$ & $60.20 \mathrm{ab}$ \\
\hline \multirow{2}{*}{ Dimethion 40 EC } & \multirow{2}{*}{ Dimethoate } & 0.05 & $60.03 \mathrm{bc}$ & 71.27 abc & 53.76 abc \\
\hline & & 0.025 & $55.13 \mathrm{~cd}$ & 68.23 bc & $49.17 \mathrm{bc}$ \\
\hline \multirow{2}{*}{ Fentro 50 EC } & \multirow{2}{*}{ Fenetrothion } & 0.05 & 51.03 de & $64.87 \mathrm{bc}$ & $45.17 \mathrm{bc}$ \\
\hline & & 0.025 & $46.20 \mathrm{e}$ & $60.50 \mathrm{c}$ & $40.00 \mathrm{c}$ \\
\hline LSD value at $5 \%$ & & & 8.52 & 10.25 & 14.55 \\
\hline
\end{tabular}

The average aphid infested plants (\%) in control treatment were 43.75, 52.5 and 60.8 at 1 , 4 and 7 days, respectively, after first spray of insecticides.

\section{Effect of insecticides on reduction of aphid infested mustard plant after second spray}

The percent reduction of aphid infested plants ranged from 42.49 to $68.40 \%$ at 1 DAT, 57.74 to $81.28 \%$ at 4 DAT and 41.27 to $66.54 \%$ at 7 DAT (Table 2). The significant differences of reduction on the aphid infested plants were found to be similar in both first and second spraying of insecticide. The highest reduction of aphid infested plants was observed in Metasystox-R treated plots with its high dose and the lowest at low dose of Fentro. Among the insecticides, Metasystox-R was more effective against mustard aphid. Similar findings were also obtained by Islam et al. (1990), Thomas and Phadke (1992), Upadhyay and Agrawal (1993), Thomas and Phadke (1993), and Nirmala et al. (2001).

Table 2. Percentage of reduction of aphid infested mustard plants after second spray of insecticides

\begin{tabular}{|c|c|c|c|c|c|}
\hline \multicolumn{2}{|c|}{ Name of insecticides } & \multirow{2}{*}{$\begin{array}{c}\text { Dose } \\
(\%)\end{array}$} & \multicolumn{3}{|c|}{ Reduction of aphid infested plants (\%) } \\
\hline Trade name & Common name & & $1 \mathrm{DAT}$ & $4 \mathrm{DAT}$ & $7 \mathrm{DAT}$ \\
\hline \multirow{2}{*}{ Metasystox-R 25EC } & \multirow{2}{*}{$\begin{array}{l}\text { Oxydemeton } \\
\text { methyl }\end{array}$} & 0.05 & $68.40 \mathrm{a}$ & $81.28 \mathrm{a}$ & $66.54 \mathrm{a}$ \\
\hline & & 0.025 & $61.77 \mathrm{ab}$ & $75.93 \mathrm{ab}$ & $58.19 \mathrm{ab}$ \\
\hline \multirow{2}{*}{ Dimethion 40 EC } & \multirow{2}{*}{ Dimethoate } & 0.05 & $57.42 \mathrm{abc}$ & $71.36 \mathrm{abc}$ & $54.97 \mathrm{abc}$ \\
\hline & & 0.025 & 51.36 bcd & 67.26 bcd & $50.24 \mathrm{bc}$ \\
\hline \multirow{2}{*}{ Fentro 50 EC } & \multirow{2}{*}{ Fenetrothion } & 0.05 & $46.99 \mathrm{~cd}$ & $61.77 \mathrm{~cd}$ & $46.22 \mathrm{bc}$ \\
\hline & & 0.025 & $42.49 \mathrm{~d}$ & $57.74 \mathrm{~d}$ & $41.27 \mathrm{c}$ \\
\hline LSD value at $5 \%$ & & & 11.27 & 11.89 & 12.90 \\
\hline
\end{tabular}

Means in a column followed by the same letter(s) are not significantly different.

The average aphid infested plants (\%) in control treatment were 47.22, 61.43 and 70.35 at 1, 4 and 7 days, respectively, after second spray of insecticides.

DAT $=$ Days after treatment. 


\section{Effect of insecticides on aphid population after first spray}

The percent reduction of aphid population differed significantly among the treatments (Table 3). The reduction of aphid population ranged from 68.78 to $91.22 \%$ at 1 DAT, 75.20 to $99.44 \%$ at 4 DAT, 28.67 to $86.26 \%$ at 7 DAT. At 1 DAT, the highest aphid population reduction (91.22\%) was observed in the Metasystox-R treated plants with high dose. The lowest aphid population reduction (68.78\%) was observed in Fentro treated plots applied at low dose and there was no significant difference between high and low dose of Fentro treated plots. At 4 DAT, the highest aphid population reduction was (99.44\%) found in the Metasystox-R treated plots sprayed at high dose and was statistically identical to its low dose. Both doses of Metasystox-R reduced high aphid population followed by high and low doses of Dimethion. Lowest aphid population reduction (75.20\%) was observed at the low dose of Fentro which was statistically not similar from all other treatments. At 7 DAT, the highest aphid population reduction (86.26\%) was recorded from Metasystox-R treated plot applied at high dose. The lowest aphid population reduction $(28.67 \%)$ was recorded from lower dosed Fentro treated plot. In all the treatments at 7 DAT, percent reduction of aphid population were statistically dissimilar from each other irrespective of high and low doses.

Table 3. The reduction of aphid population after first spray with insecticides

\begin{tabular}{|c|c|c|c|c|c|}
\hline \multicolumn{2}{|c|}{ Name of insecticides } & \multirow{2}{*}{$\begin{array}{c}\text { Dose } \\
(\%)\end{array}$} & \multicolumn{3}{|c|}{ Reduction of aphid population (\%) } \\
\hline Trade name & Common name & & $1 \mathrm{DAT}$ & $4 \mathrm{DAT}$ & $7 \mathrm{DAT}$ \\
\hline \multirow{2}{*}{ Metasystox-R 25EC } & \multirow{2}{*}{$\begin{array}{l}\text { Oxydemeton } \\
\text { methyl }\end{array}$} & 0.05 & $91.22 \mathrm{a}$ & $99.44 \mathrm{a}$ & $86.26 \mathrm{a}$ \\
\hline & & 0.025 & $86.63 \mathrm{~b}$ & $97.61 \mathrm{a}$ & $81.45 \mathrm{~b}$ \\
\hline \multirow{2}{*}{ Dimethion $40 \mathrm{EC}$} & \multirow{2}{*}{ Dimethoate } & 0.05 & $82.37 \mathrm{~b}$ & $92.37 \mathrm{~b}$ & $73.77 \mathrm{c}$ \\
\hline & & 0.025 & $82.37 \mathrm{~b}$ & $90.35 \mathrm{~b}$ & $63.45 \mathrm{~d}$ \\
\hline \multirow{2}{*}{ Fentro 50 EC } & \multirow{2}{*}{ Fenetrothion } & 0.05 & $71.81 \mathrm{c}$ & $85.50 \mathrm{c}$ & $45.65 \mathrm{e}$ \\
\hline & & 0.025 & $68.78 \mathrm{c}$ & $75.20 \mathrm{~d}$ & $28.67 \mathrm{f}$ \\
\hline LSD value at $5 \%$ & & & 4.334 & 2.704 & 3.344 \\
\hline
\end{tabular}

The average number of aphid population in control treatment were 24.06, 35.00, and 54.80 at 1,4 , and 7 days, respectively, after first spray of insecticides.

\section{Effect of insecticides on aphid population after second spray}

The reduction of aphid population ranged from 65.30 to $91.09 \%$ at 1 DAT, 73.61 to $99.37 \%$ at 4 DAT, and 30.50 to $85.11 \%$ at 7 DAT as presented in Table 4 . In second spray, the aphid population reduced more or less similar to that of first spray after 1, 4, and 7 days of treatment. All the insecticides were found to be effective, but among them, the higher doses were more effective against aphids. 
The higher reduction of aphid population was found after 4 days of first and second application of insecticides. Lower reduction of population was observed after 7 days of insecticide application indicating decrease of effectiveness with the increasing of time. Significantly the highest reduction was observed in Metasystox-R treated plots with higher dose at 1, 4, and 7 days after first and second spray. Upadhyay and Agrawal (1993) reported that Oxydemeton methyl $(0.025 \%)$ was the most toxic to mustard aphid. Nirmala et al. (2001) recommended Metasystox $(0.025 \%)$ for the control of mustard aphid. All the findings are more or less in agreement with the findings of the present study. Few variations were found which might be due to the variation of doses of insecticides and place.

Table 4. The reduction of aphid population after second spray with insecticides.

\begin{tabular}{|c|c|c|c|c|c|}
\hline \multicolumn{2}{|c|}{ Name of insecticides } & \multirow{2}{*}{$\begin{array}{l}\text { Dose } \\
(\%)\end{array}$} & \multicolumn{3}{|c|}{ Reduction of aphid population (\%) } \\
\hline Trade name & Common name & & $1 \mathrm{DAT}$ & $4 \mathrm{DAT}$ & $7 \mathrm{DAT}$ \\
\hline \multirow{2}{*}{ Metasystox-R 25EC } & \multirow{2}{*}{$\begin{array}{l}\text { Oxydemeton } \\
\text { methyl }\end{array}$} & 0.05 & $91.09 \mathrm{a}$ & $99.37 \mathrm{a}$ & 85.11 a \\
\hline & & 0.025 & $88.17 \mathrm{ab}$ & $92.11 \mathrm{~b}$ & $76.60 \mathrm{~b}$ \\
\hline \multirow{2}{*}{ Dimethion 40 EC } & \multirow{2}{*}{ Dimethoate } & 0.05 & $82.30 \mathrm{~b}$ & $91.11 \mathrm{~b}$ & $72.60 \mathrm{c}$ \\
\hline & & 0.025 & $73.91 \mathrm{c}$ & $88.75 \mathrm{~b}$ & $59.51 \mathrm{~d}$ \\
\hline \multirow{2}{*}{ Fentro 50 EC } & \multirow{2}{*}{ Fenetrothion } & 0.05 & $72.20 \mathrm{c}$ & $85.16 \mathrm{c}$ & $48.40 \mathrm{e}$ \\
\hline & & 0.025 & $65.30 \mathrm{~d}$ & $73.61 \mathrm{~d}$ & $30.50 \mathrm{f}$ \\
\hline LSD value at $5 \%$ & & & 6.726 & 3.268 & 2.593 \\
\hline
\end{tabular}

Means in a column followed by the same letter(s) are not significantly different. The average number of aphid population in control treatment were 109.83, 54.73 and 71.32 at 1, 4, and 7 days, respectively, after second spray of insecticides.

DAT $=$ Days after treatment.

\section{Effect of insecticides on $C$. septempunctata after first spray}

Percent reduction of $C$. septempunctata after first spray differed significantly among the treatments (Table 5). The reduction of the predator ranged from 60.92 to $85.74 \%$ at 1 DAT, 49.27 to $86.72 \%$ at 4 DAT, and 29.81 to $76.28 \%$ at 7 DAT. At 1 DAT, the highest percent reduction (85.74\%) was observed in the Fentro treated plot with high dose, which was statistically similar to that in the plots of its low dose. The lowest percent reduction (60.92\%) was observed in the Dimethion treated plant with low dose, which was statistically identical to its high dose (62.41\%). Both doses of Metasystox-R reduced predator population higher than Dimethion, but lower than Fentro treated plots. At 4 DAT, the highest percent reduction of the $C$. septempunctata was observed in the Fentro treated plots with high dose (86.72\%) followed by low dose of Fentro (79.03\%) and high dose of Metasystox-R (79.00\%). The lowest percent reduction was 
found at the low dose of Dimethion (49.27\%) and which was not statistically similar as compared to other treatments. At $7 \mathrm{DAT}$, the highest percent reduction of the predator was obtained in Fentro treated plant with high dose (76.28\%), which was identical at its low dose (73 .28\%). The lowest percent reduction was found in the Dimethion treated plants with low dose (29.81\%) and this was statistically different from other treatments.

Table 5. The reduction of $C$. septempunctata after first spray of insecticides.

\begin{tabular}{|c|c|c|c|c|c|}
\hline \multicolumn{2}{|c|}{ Name of insecticides } & \multirow{2}{*}{$\begin{array}{c}\text { Dose } \\
(\%)\end{array}$} & \multicolumn{3}{|c|}{ Reduction of C. septempunctata (\%) } \\
\hline Trade name & Common name & & $1 \mathrm{DAT}$ & $4 \mathrm{DAT}$ & $7 \mathrm{DAT}$ \\
\hline \multirow{2}{*}{ Metasystox-R 25EC } & \multirow{2}{*}{$\begin{array}{l}\text { Oxydemeton } \\
\text { methyl }\end{array}$} & 0.05 & $78.15 \mathrm{~b}$ & $79.00 \mathrm{~b}$ & $65.39 \mathrm{~b}$ \\
\hline & & 0.025 & $76.80 \mathrm{~b}$ & $72.28 \mathrm{c}$ & $51.29 \mathrm{c}$ \\
\hline \multirow{2}{*}{ Dimethion 40 EC } & \multirow{2}{*}{ Dimethoate } & 0.05 & $62.41 \mathrm{c}$ & $54.64 \mathrm{~d}$ & $47.44 \mathrm{c}$ \\
\hline & & 0.025 & 60.92 c & $49.27 \mathrm{e}$ & $29.81 \mathrm{~d}$ \\
\hline \multirow{2}{*}{ Fentro 50 EC } & \multirow{2}{*}{ Fenetrothion } & 0.05 & 85.74 a & $86.72 \mathrm{a}$ & $76.28 \mathrm{a}$ \\
\hline & & 0.025 & 83.33 a & $79.03 \mathrm{~b}$ & $73.72 \mathrm{a}$ \\
\hline LSD value at $5 \%$ & & & 4.122 & 3.934 & 3.985 \\
\hline
\end{tabular}

The average number of $C$. septempunctata in control treatment were 1.99, 2.35, and 3.00 at 1,4, and 7 days, respectively, after first spray of insecticides.

\section{Effect of insecticides on $C$. septempunctata after second spray}

The percent reduction of the predator at 1 DAT was maximum $(83.50 \%)$ in the Fentro treated plot sprayed with high dose and it was statistically identical when Fentro was applied with low dose. The lowest percent reduction was recorded in Dimethion treated plots applied with low (58.20\%) and high (60.15\%) doses. At 4 DAT, the highest percent reduction was observed in Fentro sprayed plot (86.02\%) with high dose followed by low dose of Fentro (80.00\%) and high dose of Metasystox-R (78.05\%) treated plots. The lowest percent reduction was observed in Dimethion (46.28\%) treated plots with low dose. From this study, it was evident that both doses of Fentro were highly toxic to the predator. On the other hand, Dimethion 40 EC $(0.025 \%)$ proved to be safer insecticide to the predator both after first and second spray. Olszak (1982), and Sharma and Adlakha (1986) found that Fenitrothion was most toxic to the predator. Malik et al., 1998, observed that Phosphamidan was detrimental for C. septempunctata and reduced $73.10 \%$ predator population. Rajagopal and Kareen (1984), and Tripathi et al. (1988) reported that Dimethion was safe to the predator. All these findings are in agreement with the findings of the present study. Few variations might be due to the variation of doses of insecticides and place. 
Table 6. The reduction of $C$. septempunctata after second spray of insecticides.

\begin{tabular}{|c|c|c|c|c|c|}
\hline \multicolumn{2}{|c|}{ Name of insecticides } & \multirow{2}{*}{$\begin{array}{c}\text { Dose } \\
(\%)\end{array}$} & \multicolumn{3}{|c|}{ Reduction of C. septempunctata (\%) } \\
\hline Trade name & Common name & & $1 \mathrm{DAT}$ & $4 \mathrm{DAT}$ & $7 \mathrm{DAT}$ \\
\hline \multirow{2}{*}{ Metasystox-R 25EC } & \multirow{2}{*}{$\begin{array}{l}\text { Oxydemeton } \\
\text { methyl }\end{array}$} & 0.05 & $76.12 \mathrm{~b}$ & $78.05 \mathrm{~b}$ & $68.20 \mathrm{~b}$ \\
\hline & & 0.025 & $72.20 \mathrm{~b}$ & $73.16 \mathrm{c}$ & $53.30 \mathrm{c}$ \\
\hline \multirow{2}{*}{ Dimethion 40 EC } & \multirow{2}{*}{ Dimethoate } & 0.05 & $60.15 \mathrm{c}$ & $53.50 \mathrm{~d}$ & $48.12 \mathrm{c}$ \\
\hline & & 0.025 & $58.20 \mathrm{c}$ & $46.28 \mathrm{e}$ & $26.62 \mathrm{~d}$ \\
\hline \multirow{2}{*}{ Fentro 50 EC } & \multirow{2}{*}{ Fenetrothion } & 0.05 & $83.50 \mathrm{a}$ & $86.02 \mathrm{a}$ & $79.01 \mathrm{a}$ \\
\hline & & 0.025 & $80.38 \mathrm{a}$ & $80.00 \mathrm{ab}$ & $71.60 \mathrm{~b}$ \\
\hline LSD value at $5 \%$ & & & 3.936 & 5.035 & 5.494 \\
\hline
\end{tabular}

Means in a column followed by the same letter(s) are not significantly different. The average number of $C$. septempunctata in control treatment were 1.6, 2.06, and 3.22 at 1,4 and 7 days, respectively, after second spray of insecticides.

DAT = Days after treatment.

Findings of the study indicated that Metasystox-R was the most effective against mustard aphid followed by Dimethion compared to Fentro in respect of aphid infested plants and aphid populations. The use of Fentro was found to be more toxic to the grub and adult of the predator $C$. septempunctata. Dimethion $(0.025 \%)$ proved to be safe insecticide to the predator.

\section{References}

Agarwala, B. K., S. Das and M. Senchowdhuri. 1988. Biology and food relation of Micraspis discolor an aphidophagous coccinellid in India. J. Aphidol. 2 (1-2): 7-17.

Ahmed, T. U. and A. F. M. A. Jalil. 1993. Bangladesher Krishir Onistokari Pokamakor, Jiban Brittanta 0 Nyantron (Bangla). Bangla Academy, Dhaka, 381 pp.

Anonymous. 2001a. Estimation of oilseed. p. 66. In: year book of Agricultural statistics of Bangladesh 1999. BBS, Statistics Division, Ministry of Planning, Govermment of the People's Republic of Bangladesh, Dhaka, 362p.

Anonymous. 200lb. Import of selected agricultural products and requisition, 1993-94 to 1997-98. P. 345 In: Yearbook of Agricultural Statistics of Bangladesh, 1999. BBS, Statistics Division, Ministry of Planning, Government of the People's Republic of Bangladesh, Dhaka, 362p.

Anonymous. 1995. Assessment of losses due to aphid infestation at different growth stages of mustard. Ann. Rept. 1994-95, Bangladesh Agric. Res. Inst., Regional Agric. Res. Station, Jessore, 120 pp.

Islam, N., M. I. M. Bhuiyah, A. Begum, and M. A. Karim. 1990. Field evaluation of foliar insecticides for the control of the mustard aphid, L. erysimi. Bangladesh J. Zool. 18(2): 185-188.

Kalra, V. K. 1988. Population dynamics of various predators associated with mustard aphid, L. erysimi Kalt. J. Bio. Control. 2(2): 77-79. 
Malik, Y.P., B. Deen, S. V. Singh, and G. Singh. 1998. Economics of different insecticidal schedules against mustard aphid Lipaphis erysimi with safety to natural fauna on mustard. Indian J. Ent. 60 (1): 50-56.

Morzia, B. and S. B. Huq. 1991. Evaluation of different genotypes of Indian mustard (Brssica juncea) for their reaction to mustard aphid L. erysimi. Indian J. Agril. Sci. 61(3): 210-213.

Nirnala, D., D. Indra, R. Desh, N. Devi, I. Dogra, and D. Raj. 2001. Comparative field efficacy of insecticides against mustard aphid. L. erysimi on rapeseed crop in mid hill zone of Himachal Pradesh. J. Entomol. Res. 25 (2) : 93-96.

Olszak, R. 1982. Impact of different pesticides on lady bird beetles (Coccinellidae: Coleoptera). Roczniki Nauk Rolniczych-E-Ochrona-Roslin. 12(1-2): 141-149.

Rajagopal, S. and A. Kareen. 1984. Studies on the toxic effect of some insecticides on parasites and predator $M$ sexmaculatus of chilies aphid, M persicae. Pranikee 4: 308315.

Rouf, F. M. A. and K. H. Kabir. 1997. Economic efficacy of some insecticides for the control of mustard aphid, L. erysimi Kalt. Bangladesh J. Entomol. 7 (1 \& 2): 1-7.

Setokuchi, 0. 1983. Seasonal prevalence of Myzus persicae Sulzer. and L. etysimi Kalt. (Homoptera: Aphididae) Kagoshima prefecture. Japanase J. Appil. Entomol. Zool. 21: 219-233.

Sharma, H.C. and R. L. Adlakha. 1986. Toxicity of some insecticides to the adults of Coccinella septempunctata L. after predating upon poisoned cabbage aphid Brevicoryne brassicae L. Indian J. Ent. 48(2) : 204-211.

Thomas, J. and K. G. Phadke. 1992. Field efficacy of Chlorpyriphos and Quinaiphos EC and Dusts as compared to Oxydemeton methyl EC against aphid L. erysimi Kalt. on rapeseed crop. Indian J. Ent. 54 (2): 150-163.

Thomas, J. and K. G. Phadke. 1993. Residual toxicity and persistence of Chlorpyriphos, Quinaiphos and Oxydemeton methyl to aphid, L. erysimi Kalt. Indian J. Ent. 55 (3): 275-280.

Tripathi, N. L. M., G. C. Sochan and S. K. Verma. 1988. Relative toxicity and safety to some insecticides to Coccinella septempunctata. Indian J. Pl. Prot. 16 (1) : 87-88.

Upadhyay, S. and R. K. Agrawal. 1993. Persistent toxicity of some insecticides against $L$. erysimi Kalt. on mustard. Indian J. P1. Prot. 21(1): 104-105.

Upadhyay, S. and R. K. Agrawal. 1993. Efficacy of different insecticides on incidence of mustard aphid, L. erysimi on Indian mustard (Brassica juncea) and its economics. Indian J. Agril. Sci. 63 (8): 522-525. 